\title{
Chemical composition, antioxidant activity and antibacterial mechanism of action from Marsilea minuta leaf hexane: methanol extract
}

\author{
Selvaraj Arokiyaraj ${ }^{1 \dagger}$, Rajaraman Bharanidharan ${ }^{2,3 \dagger}$, Paul Agastian $^{4}$ and Hakdong Shin ${ }^{1 *}$
}

\begin{abstract}
Background: In the present study, hexane: methanol (50:50) leaf extract of Marisela minuta has been evaluated for its chemical composition, antioxidant effect and the antimicrobial mechanism of action against food borne pathogenic bacteria.

Results: The phytochemical evaluation of extract by GC/MS revealed the major abundance of benzoic acid-4-ethoxyethyl ester (43.39\%) and farnesol acetate (18.42\%). The extract exhibited potential antioxidant and free radical scavenging properties with promising antibacterial activities against the test pathogens with Pseudomonas aeruginosa being the most susceptible with maximum inhibition zone $(17 \mathrm{~mm})$ and $I C_{50}$ value of $125 \mu \mathrm{g}$, respectively. The significant $(p<0.05)$ increase in intracellular super oxide dismutase $(S O D)$, protein leakage, extracellular alkaline phosphatase and lactate dehydrogenase in treated test pathogens suggested an increase in oxidative stress reveling the mechanism of action of phytochemicals. Scanning electron microscopy analysis of treated pathogens also showed swollen and distorted cells. The bioactive molecules in the extract were efficiently docked with virulent enzymes and farnesol acetate showed best energy value of -5.19 and $-4.27 \mathrm{kcal} / \mathrm{mol}$ towards Topoisomerase IV and SHV-2 respectively. Benzoic acid-4-ethoxyethyl ester showed best binding against TEM-72 with low binding energy value of $-4.35 \mathrm{kcal} / \mathrm{mol}$.
\end{abstract}

Conclusion: Due to its antioxidant and antibacterial properties, the leaf extract of M. minuta may act as promising natural additives to prevent food spoilage bacteria.

Keywords: Marsilea minuta, Leaf extract, Antioxidant, Natural preservative, Docking analysis

\section{Introduction}

The rise in prevalence of multi-drug resistant bacteria has been accredited to undiscriminating use of broadspectrum antibiotics [1-3]. Nowadays increase of emerging antibiotic resistant bacteria has become a worldwide concern. These drug resistant organisms also can contribute to the risk of food contamination. There have

\footnotetext{
*Correspondence: hshin@sejong.ac.kr

${ }^{\dagger}$ Selvaraj Arokiyaraj and Rajaraman Bharanidaran equal contribution to this research work

${ }^{1}$ Department of Food Science and Biotechnology, College of Life Science,

Sejong University, Seoul 05006, Republic of Korea

Full list of author information is available at the end of the article
}

been reports for some drug resistant bacteria like Pseudomonas aeruginosa, Staphylococcus aureus and Enterococcus faecalis as potent food contaminants $[4,5]$. The addition of preservatives has been an effective method to control microbial contamination and authorised synthetic preservatives are still being used to prevent microbial spoilage of processed food. Recently, there is an increasing customer awareness regarding to chemical preservatives in processed food. Considering the demand for natural products with high safety and biological properties, plant compounds has attracted the attention of researchers globally. 
Plant secondary metabolites like flavonoids and other phenolic compounds are widely occurring phytochemicals reported to possess antioxidant and antimicrobial properties [6-8]. Many research studies reported plant secondary metabolites exhibit good antioxidant properties $[9,10]$ and the metabolites from plant origin have a wide spectrum of antimicrobial action against foodborne pathogens and spoilage bacteria [11]. Therefore, the pharmaceutical industries are still in the search of active drug molecules from the unexploited medicinal plants, which exhibit good biological effects (antioxidant and preservative). In plant extracts, massive amount of constituents are present but not all of those are related to pharmaceutical applications. By using chromatography techniques, these phytochemical constituents can be identified, sub-fractionated and tested for their biological properties and many studies reported the chemical composition from plant extracts using GC-MS analysis [12, 13].

In silico studies are preliminary approach to screening novel drug candidates and an emerging strategy to reduce many complexities of drug discovery process and this method has played important role in the rational drug design to identify the biological or phytocompounds potential against antimicrobial resistant proteins [14]. In the present study, we selected Marsilea minuta Linn (Marsileaceae) leaves material for exploring its biological potential. M. minuta commonly found in the banks of ponds and canals and as a weed in the wet rice fields and distributed throughout India. It has a great traditional medicinal value possessing anti-infertility [15], antidepressant [16], hypocholesterolemic [17] and hepatoprotective activities [18]. Earlier studies investigated the antibacterial activity of gold nanoparticles synthesized from the $M$. minuta leaf extract against Escherichia coli and Staphylococcus aureus [19] and antibacterial activity against various pathogens have also been reported [20]. However, there are no reports on the complete phytochemical composition and the mode of action of extracts from $M$. minuta against food borne pathogens. Therefore, the objective of this work is to evaluate the chemical composition, antioxidant activity, antimicrobial activity, and the mode of action against food borne pathogens of M. minuta leaf extract.

\section{Results and discussion}

\section{Chemical composition of the $M$. minuta leaves extract}

GC-MS analysis of $M$. minuta leaves extract (50\% hexane:50\% methanol) identified 12 compounds and the predicted constituents in the extracts were listed in Table 1. The major compounds were benzoic acid-4-ethoxy-, ethyl ester (43.39\%), a monoester of benzoic acid and farnesol acetate $(18.42 \%)$, a sesquiterpene compound. These two chemical molecules selected for molecular docking studies with target proteins TEM-72 and Topoisomerase IV for their possible antibacterial mechanism of action. Earlier studies reported that farnesol was potentially active against Staphylococcus aureus and Streptococcus mutans $[21,22]$ and benzoic acid-4-ethoxy-, ethyl ester used in stabilizers in preparation of packaging material [23]. Next, phenol, 2,4-bis (1,1-dimethylethyl) (8.37\%), a phenolic compound; oxacycloheptadec-8-en-2-one (5.68\%), a lactone; and trans-farnesol (5.11\%), an oxygenated sesquiterpene were identified. The presence of phenolic compounds may possess antioxidant and antibacterial mechanism and there are numerous reports available on phenolic compounds exhibiting antioxidant, antimicrobial, heptaprotective and antidiabetic potential [24, 25].

Table 1 GC-MS analysis of Marsilea minuta leaves extract

\begin{tabular}{|c|c|c|c|c|}
\hline Peak no & Components & Class of compound & Retention time & Area \% \\
\hline 1. & Phenol, 2,4-bis (1,1-dimethylethyl) & Phenol & 13.52 & 8.37 \\
\hline 2. & Benzoic acid, 4-ethoxy-, ethyl ester & Aromatic acid ester & 13.76 & 43.39 \\
\hline 3. & 1,6,10-dodecatrien-3-ol,3,7,11-trimethyl & Oxygenated sesquiterpene & 14.20 & 2.61 \\
\hline 4. & Trans-Farnesol & Oxygenated sesquiterpene & 16.00 & 5.11 \\
\hline 5. & 2,6,10-Dodecatrien-1-ol,3,7,11-trimethyl-acetate & Sesquiterpene & 16.96 & 1.71 \\
\hline 6. & Farnesol, acetate & Sesquiterpene & 17.22 & 18.42 \\
\hline 7. & Phthalic acid, isobutyl undecyl ester & Diester & 17.54 & 4.91 \\
\hline 8. & 7,9-Di-tert-butyl-1-oxaspiro(4,5)deca-6,9-diene-2,8-dione & Spirolactone & 18.05 & 1.84 \\
\hline 9. & Oxacycloheptadec-8-en-2-one & Lactone & 18.46 & 5.68 \\
\hline 10. & 1,2-Benzenedicarboxylic acid, butyl-2-methylpropylester & Diester & 18.51 & 4.84 \\
\hline 11. & Octadec-9-enoic acid & Unsaturated fatty acid & 19.64 & 1.89 \\
\hline 12. & Oleic acid & Unsaturated fatty acid & 21.23 & 1.22 \\
\hline
\end{tabular}

Compound proportions were calculated from the chromatograms obtained on the TG-5MS column. The percentage of the compounds detected in the GC that was calculated based on the relative area of individual compounds to the total area of the components identified from the extract 

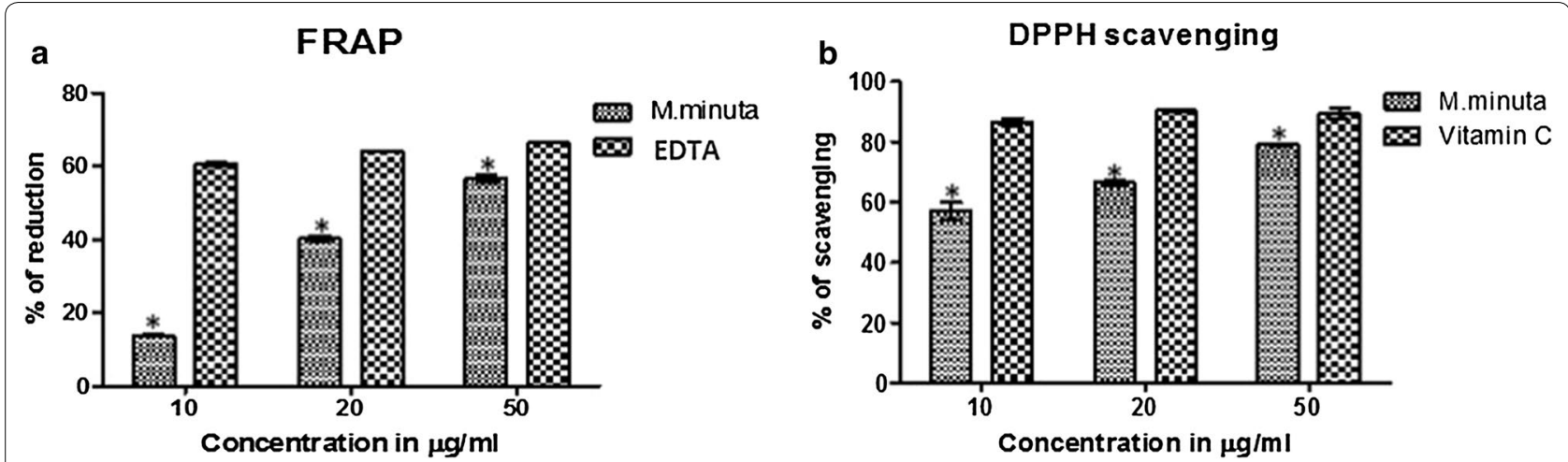

Fig. 1 a FRAP scavenging activity of M. minuta leaves extract (\%), b percentage inhibition of DPPH free radical by M. minuta leaves extract. Values represent the mean \pm SEM of triplicate, independent experiments; the values labeled with Asterisk indicate statistically significant difference compared with standard compound as determined by Student t-test $(p<0.05)$

Table 2 IC50 value of FRAP and DPPH radical scavenging activity

\begin{tabular}{lcll}
\hline Antioxidant activity & M. minuta & EDTA & Vitamin C \\
\hline FRAP $\mu \mathrm{g} / \mathrm{ml}$ & 37.48 & 7.42 & - \\
DPPH $\mu \mathrm{g} / \mathrm{ml}$ & 8.94 & - & 5.77 \\
\hline
\end{tabular}

Therefore, the chemical constituents found in $M$. minuta leaves extracts may play major roles in the antioxidant and antimicrobial properties.

\section{Ferric reducing antioxidant power assay}

The $M$. minuta extract showed a significant dose-dependent inhibition of FRAP activity. The highest reducing activity $(60 \%)$ found in the concentration of $50 \mu \mathrm{g} / \mathrm{ml}$ when compared with the standard EDTA (Fig. 1a). The $\mathrm{IC}_{50}$ concentrations for the standard and $M$. minuta leaves extracts were found to be 7.42 and $37.48 \mu \mathrm{g} / \mathrm{ml}$ (Table 2) respectively. The reducing ability effect of $M$. minuta extracts was mainly due the presence of phytochemical compounds. Also, the presence of phenolic compounds can contribute the reduction potential. In general, the antioxidant activity of phenolic compounds is due to their ability to chelate metal ions involved in the generation of free radicals [26]. In support of the antioxidant effect, GC-MS spectrum confirmed the presence of phenolic compounds.

\section{Scavenging activity of DPPH radicals}

This method depends on the reduction of purple DPPH radicals to a yellow colored diphenyl picryl hydrazine. The reduction of color of DPPH solution indicates an increase of the DPPH radical scavenging activity [27]. The percentage of DPPH scavenging in the presence $M$. minuta leaves extracts at different concentrations were
Table 3 Antibacterial activity (zone of inhibition, $\mathrm{mm}$ ) of $M$. minuta leaves extract

\begin{tabular}{lll}
\hline Bacterial species & M. minuta & Streptomycin \\
\hline E. faecalis & $16 \pm 0.42$ & $26 \pm 0.72$ \\
B. subtilis & $16 \pm 0.38$ & $24 \pm 0.45$ \\
P. aeruginosa & $17 \pm 0.27$ & $25 \pm 0.33$ \\
K. pneumonia & $12 \pm 0.34$ & $26 \pm 0.76$ \\
\hline
\end{tabular}

Values are mean of experiments performed in triplicate and data are expressed as mean $\pm \mathrm{SD}$

shown in Fig. 1b. The result showed a significant dosedependent inhibition of DPPH activity and the values were found to be significant $(\mathrm{p}<0.05)$. The $\mathrm{IC}_{50}$ concentrations for the standard (vitamin C) and M. minuta extracts were found to be 5.77 and $8.94 \mu \mathrm{g} / \mathrm{ml}$, respectively. The extract exhibited concentration dependent activity and the presence of certain phytochemicals may result in the free radical scavenging potential. Moreover, our results are in agreement with previous findings demonstrating DPPH scavenging effect of methanolic extract of M. quadrifolia [28].

\section{Antibacterial activity}

In this study, we tested antibacterial ability of $M$. minuta leaves extract against Bacillus subtilis, Staphylococcus aureus, Enterococcus faecalis, Klebsiella pneumonia and Pseudomonas aeruginosa. These bacteria are associated with food borne diseases, food spoilage and multi drug resistant bacteria [29]. Antibacterial assay results showed $M$. minuta leaves extract exhibited good inhibitory effect against all of the test strains (Table 3). Among the tested pathogens $P$. aeruginosa exhibited the maximum inhibition zone $(17 \mathrm{~mm})$. Our results are in accordance with Gupta et al. [30], that the ethanolic extract of Achyranthes aspera, Cynodon dacynodon dactylon, Lantana camara 
and Tagtes patula showed effective antibacterial activity against $S$. aureus, $P$. aeruginosa and B. subtilis. Likewise, the minimum inhibitory concentration (MIC) of the $M$. minuta leaves extract against the tested strains of various bacterial pathogens with concentration ranging from 125 to $250 \mu \mathrm{g} / \mathrm{ml}$ (Table 4). Our results are in agreement with the reports of Rios and Recio [31], that plant extract possessing an MIC value equaling or less than $1000 \mu \mathrm{g} / \mathrm{ml}$ is considered to be active and worthy antimicrobials. In the present study, $M$. minuta leaves extract possesses a variety of phytochemicals. Therefore, the antibacterial activities of $M$. minuta may be due to the presence of phenolic compounds (phenol-2,4-Bis(1,1-dimethylethyl)) as well as different concentration of aromatic acid ester, oxygenated sesquiterpene, sesquiterpene and fatty acids [32]. Similarly, Prakash and Suneetha [33] reported the presence of phenolic compound (phenol-2,4-Bis(1,1-dimethylethyl)) in the Pinus granatum extract and showed potential antioxidant activity. The probable mode of antibacterial action may be due to disruption in cell membrane, lysis and leakage of intracellular compounds [34]. However, because of the heterogeneous compositions of the M. minuta leaves extracts, the individual compounds responsible for its antimicrobial mechanism need to be identified.

\section{SOD quantification}

Superoxide dismutase (SOD) enzymes present in aerobic and anaerobic organisms responsible for the breakdown of superoxide radicals [35]. When SOD activity was high, it leads to the increase in tolerance to oxidative stress; secondly, increased stress leads to cell wall damage and cell burst. Similarly, in our study, we observed SOD quantity for all the treated bacteria was high when compared with untreated bacteria and the values were significant $(\mathrm{p}<0.05)$. The results for the quantification of SOD levels in M. minuta leaves extract treated and untreated bacteria are shown in Fig. 2a. This clearly shows that the extract exhibited a stress towards the pathogens. Similarly, Dwyer et al. [36] reported that treatment of Escherichia coli with bactericidal antibiotics induced the generation of ROS, via a common metabolic mechanism, which contributes to drug-induced killing.

Table 4 Minimum inhibitory concentration of $M$. minuta leaves extract

\begin{tabular}{ll}
\hline Species & MICs $(\boldsymbol{\mu} \mathbf{g} / \mathbf{m l})$ \\
\hline E. faecalis & 250 \\
B. subtilis & 250 \\
P. aeruginosa & 125 \\
K. pneumonia & 250 \\
\hline
\end{tabular}

\section{ALP quantification assay}

In bacteria, alkaline phosphatase (ALP) is usually located in the periplasmic space to generate free phosphate groups for uptake and use. More amount of alkaline phosphatase is usually produced during phosphate starvation and sporulation. In the present study, we observed significant increase $(\mathrm{p}<0.05)$ in the ALP level in the bacteria treated with $M$. minuta leaves extract (Fig. $2 \mathrm{~b}$ ). The increase may be because of stress imposed on the bacteria by the extract, and in order to overcome the starvation, the bacteria produces more amount of ALP. Previous studies revealed that the ALP levels were increased in Clostridium perfringens and Brachyspira hyodysenteriae upon treatment with Quinoxaline 1,4-di- $\mathrm{N}$-oxide derivatives compared to the non-treated groups [37]. Therefore, the observed significant increase in the ALP activities in the bacteria treated with $M$. minuta extract suggests an increase in the activities of the existing enzymes by the secondary metabolites.

\section{LDH quantification assay}

The effects of $M$. minuta extract on LDH activities of $S$. aureus and other bacteria were shown in Fig. 2c. The LDH activity in the treated bacterial group were high when compared to the untreated one. The values were significant $(\mathrm{p}<0.05)$ and showed a variance of 120-175 units/l. This indicate that $M$. minuta extract does interact with the bacterial cell surface. $M$. minutabacteria interaction mediated by electrostatic forces. After attachment, alternation in membrane permeability causes the leakage of cytosolic enzyme (glucose and LDH), which finally causes cell death [38].

\section{Intra cellular protein leakage}

The $M$. minuta extract was observed to induce protein leakage in all the test organisms (Fig. 2d). Both of the Gram ( $(-)$ and Gram $(+)$ bacteria showed a similar trend of protein leakage when treated with the M. minuta extract. Among all bacteria, $P$. aeruginosa had the highest damaging effect causing leakage compared to untreated bacteria $(\mathrm{p}<0.05)$. This is in agreement with the previous report by Henie et al. [39] indicating measuring protein leakage level could be used as an indicator of membrane damage.

\section{Scanning electron microscope observation}

The damage in bacterial cell wall by $M$. minuta extract treatment were extensively studied by scanning electron microscope (Fig. 3). The test bacterial strains $P$. aeruginosa, K. pneumonia, E. faecalis and B. subtilis control without $M$. minuta extract treatment showed smooth and damage free cells. Whereas, extract treated bacterial 


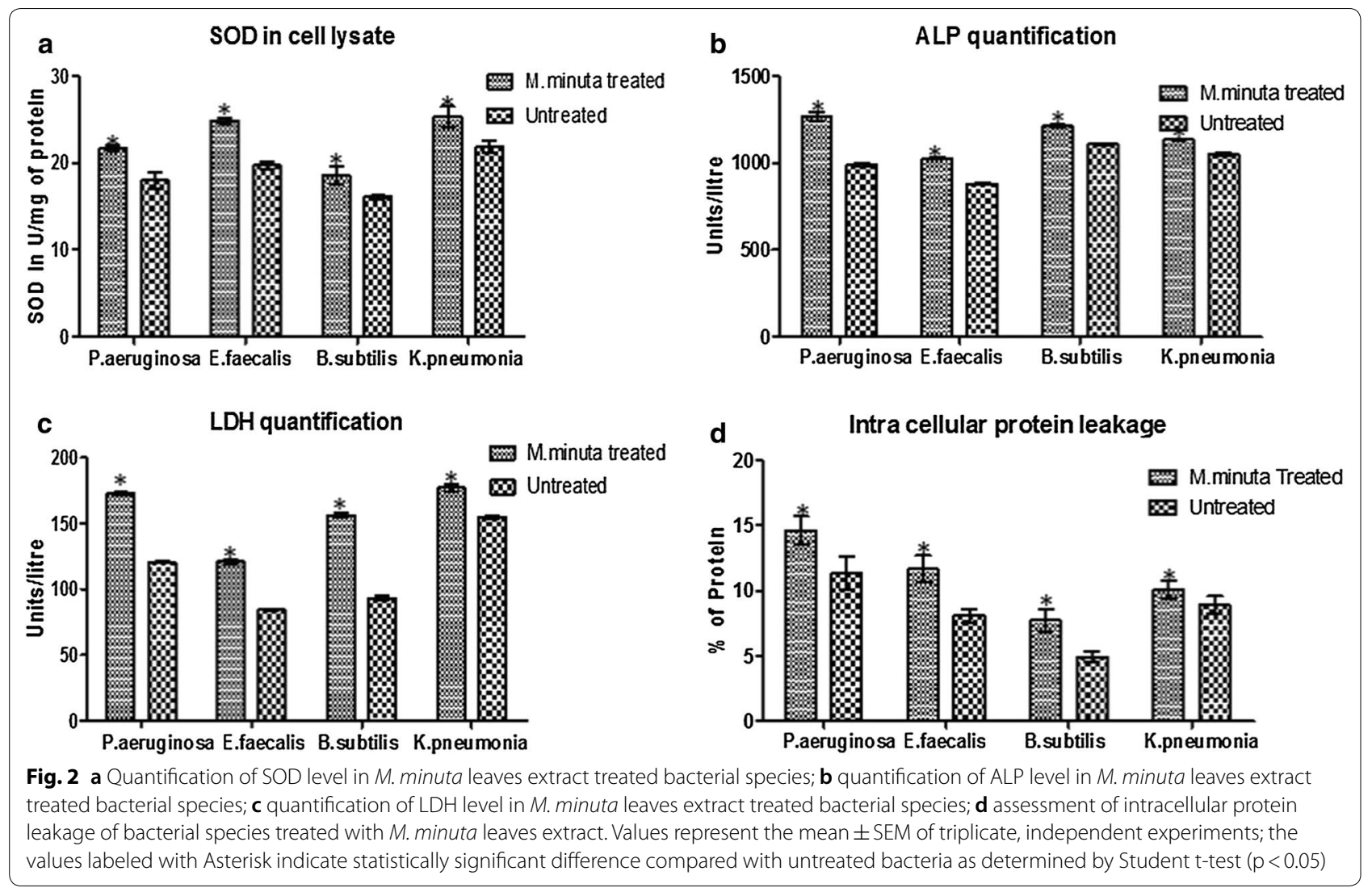

cell showed distortion in their cell morphology causing leakage of intra cellular components and results in cell death. This observation support the conclusion from lactate dehydrogenase and intra cellular protein leakage assay. Similarly, Burt and Reinders [40] observed that oregano and thyme essential oil showed potent antimicrobial properties against $E$. coli and the mode of action to be cell wall degradation; damage in cytoplasmic membrane proteins; leakage of cellular contents, and depletion of proton motive forces.

\section{Docking study of $M$. minuta ligands with target proteins}

Bacterial proteins are the ultimate target to inhibit their growth since these are the executors of many cellular functions. Production of extended-spectrum $\beta$-lactamases (ESBLs) by bacteria belonging to family Enterobacteriaceae is a deep scientific concern, since they are able to neutralize the $\beta$-lactam antibiotics making them more resistant to antibiotics. The SHV family of $\beta$-lactamases is universally found in K. pneumoniae and confers resistance to broad-spectrum penicillins such as ampicillin [41]. TEM-72 a class A, $\beta$-lactamases enzyme represent resistant factors against $\beta$-lactam antibiotics [42] and topoisomerases help in unwinding the DNA during bacteria replication [43]. Considering these factors TEM-72, SHV 2 and topoisomerases IV were selected for molecular docking studies. After docking studies, we have found that that the ligands (benzoic acid-4-ethoxy-ethyl ester and farnesol acetate) showed satisfactory binding towards the target proteins and the results are shown in Table 5 and Fig. 4. Table 5 represents the energy values of ligand receptor interaction, where farnesol acetate has the best energy value of $-5.91 \mathrm{~K} \mathrm{Cal} / \mathrm{mol}$ towards topoisomerase IV. Lower the energy value, better the ligand docked to the receptor. Hydrogen $(\mathrm{H})$ bonding

(See figure on next page.)

Fig. 3 Morphological comparison of bacteria treated with M. minuta leaves extract by scanning electron micrograph. Arrows indicates swollen cells, leakage of cell contents and change in cell shape. A1_Pseudomonas aeruginosa (Control); A2 - Pseudomonas aeruginosa (Treatment); B1-Klebsiella pneumonia (Control); B2—Klebsiella pneumonia (Treatment); C1—Enterococcus faecalis (Control); C2 — Enterococcus faecalis (Treatment); D1—Bacillus subtilis (Control); D2—Bacillus subtilis (Treatment) 


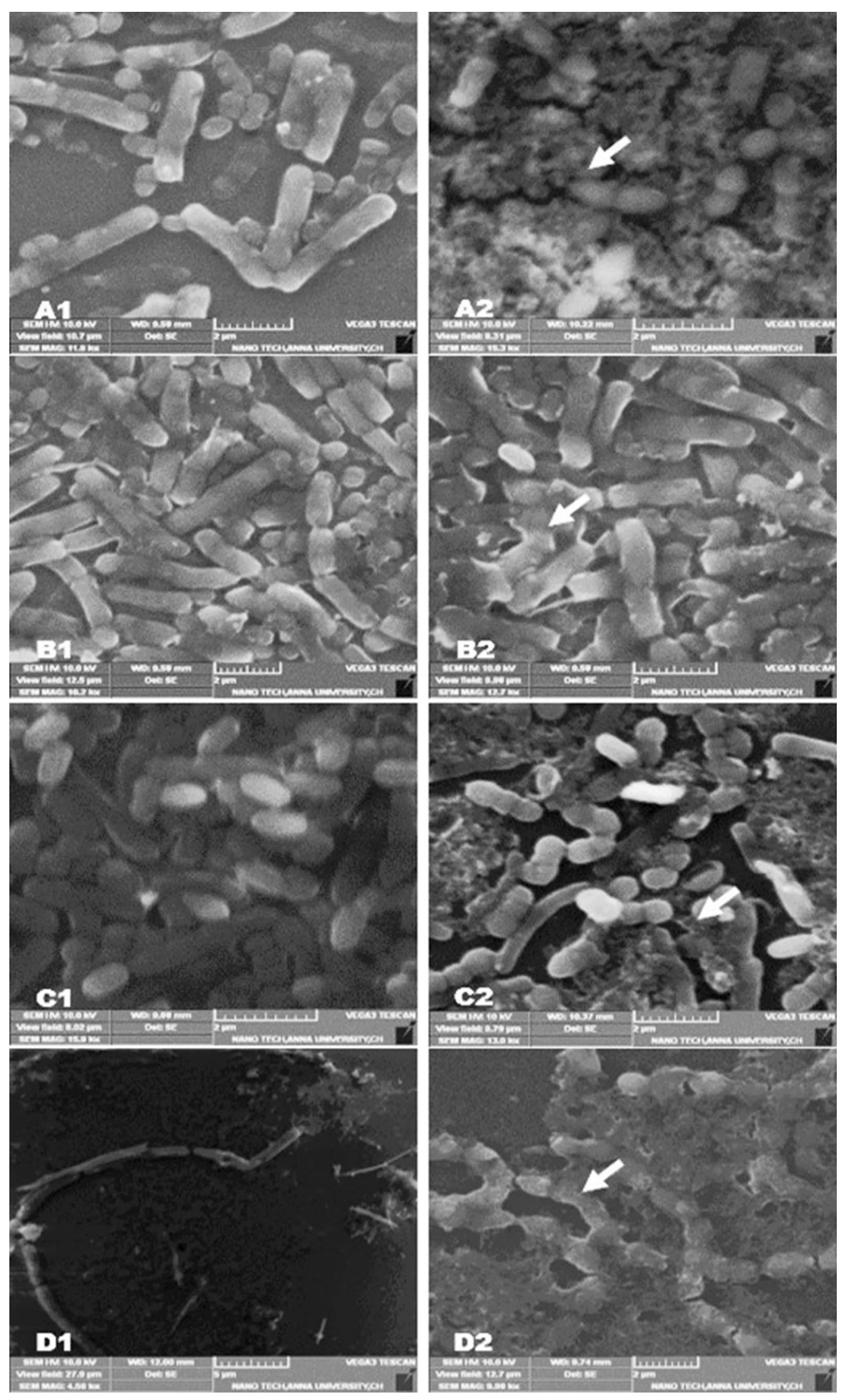


Table 5 The docking scores of the ligands with the target protein

\begin{tabular}{lll}
\hline Protein & Ligand & $\begin{array}{l}\text { Binding } \\
\text { energy (kcal/ } \\
\text { mol) }\end{array}$ \\
\hline TEM-72 (PDB ID: 3P98) & $\begin{array}{c}\text { Benzoic acid-4-eth- } \\
\text { oxy-ethyl ester }\end{array}$ & -4.35 \\
SHV-2 (PDB ID: 1N9B) & Farnesol acetate & -4.27 \\
Topoisomerase IV (PDB ID: 3LPS) & Farnesol acetate & -5.19 \\
\hline
\end{tabular}

play a critical role in determining the structure and function of any biological molecule, especially for its inhibition in a complex [44]. The ligand benzoic acid4-ethoxy-ethyl ester docked complex was stabilized by two H-bond with A:LYS 192 and B:ARG 61 of TEM-72 with lowest binding energy of $-4.35 \mathrm{kcal} / \mathrm{mol}$ (Fig. $4 \mathrm{a}$ ) and another ligand farnesol acetate is stabilized by two $\mathrm{H}$-bonds with residues of A:ALA 237 with lowest binding energy of $-4.27 \mathrm{kcal} / \mathrm{mol}$ in SHV-2 (Fig. 4b). This ligand also formed two H-bonds with A:ASP 85 and A:LYS 235 with lowest binding energy of $-5.19 \mathrm{kcal} /$ $\mathrm{mol}$ in topoisomerase IV (Fig. 4c). The in silico results showed that, the major compounds (benzoic acid4-ethoxy-ethyl ester and farnesol acetate) present in $M$. minuta extract having minimum binding energy and have good affinity toward the active pocket, thus, they may be considered as good inhibitor of topoisomerase IV, SHV-2 and TEM-72 protein. Despite from antibacterial and antioxidant activities by $M$. minuta leaves extract, this study has some limitation i.e. we have not conducted bioassay-guided fractionation of bioactive molecules present in the M. minuta and the probable mechanism (In silco studies) of action of benzoic acid4-ethoxy-, ethyl ester and farnesol acetate was based on the major compounds that was predicted by GC-MS analysis. In addition, the extract may have non-volatile bioactive compounds in addition to the reported compounds. Therefore, detailed analysis of the total chemical constituents of this plant and bioassay guided fraction of bioactive metabolite will be conducted in future studies.

\section{Experimental details}

\section{Chemical reagents and solvents}

Folin-Ciocalteu reagent, 2,2-diphenyl-1-picrylhydrazyl (DPPH), Sodium carbonate, Aluminum chloride, $O$-phenanthroline, EDTA, Nitro Blue Tetrazolium dye (NBT), $\mathrm{NaOH}, p$-nitrophenol, $\mathrm{CaCl}_{2}$,Trichloroacetic acid (TCA) and n-hexane, methanol were purchased from Sigma Chemical Co., Ltd (St. Louis, MO,USA).
All other chemicals and solvents used were of analytical grade (AR) and purchased from Himedia, India.

\section{Microorganisms}

Bacillus subtilis (ATCC 9372), Enterococcus faecalis (ATCC 29212), Klebsiella pneumoniae (ATCC 9621), Pseudomonas aeruginosa (ATCC 27853) and Staphylococcus aureus (ATCC 25923) were obtained from the Pondicherry center for biological sciences (PCBS), Pondicherry, India. All bacterial cultures were maintained in Mueller-Hinton Agar (MHA, Himedia, India) slants and stored at $-20^{\circ} \mathrm{C}$.

\section{Plant collection and extract preparation}

Fresh leaves of $M$. minuta were collected from the region of Gopalapuram, Cuddalore district, Tamil Nadu, India. A botanist authenticated the leaves specimen and the voucher specimen deposited in the laboratory. The leaves of $M$. minuta were shade dried (10 days) and powered by using grinder. For extraction, we have first extracted the sample-using methanol. Further, the methanol solution re-extracted by liquid-liquid extraction using hexane: methanol $(50: 50 \mathrm{v} / \mathrm{v})$ ratio. The later liquid-liquid extraction was conducted to remove the fat content in the methanol extract [45]. The extract yield (pale brownish in color) was $17.84 \%(\mathrm{v} / \mathrm{v})$. The extracts were dehydrated over anhydrous sodium sulfate and stored at $4{ }^{\circ} \mathrm{C}$ in airtight glass vials until use.

\section{GC-MS analysis}

The M. minuta hexane: methanol extract was analysed by a Thermo Trace 1310 (Gas chromatograph) system, fitted with a TG-5MS (Mass spectroscopy) column $(30 \times 0.25 \mathrm{~mm}(5 \%$-phenyl)-methylpolysiloxane capillary column, coating thickness $\times 0.25 \mu \mathrm{m}), 220{ }^{\circ} \mathrm{C}$ temperature injector and $250{ }^{\circ} \mathrm{C}$ temperature transfer line. The oven temperature was held at $50{ }^{\circ} \mathrm{C}$ for $5 \mathrm{~min}$, and then programmed to $250{ }^{\circ} \mathrm{C}$ at rate of $4{ }^{\circ} \mathrm{C} / \mathrm{min}$. The ionizing energy was $70 \mathrm{eV}$. The amount of sample injected was $1 \mu \mathrm{l}$ (split ratio 1:10). Identification of unknown components in $M$. minuta extracts were determined by comparing the retention times of chromatographic peaks using Quadra pole detector with the National Institute Standard and Technology (NIST MS search Program V.2.0 g) library to relative retention indices. Quantitative determinations were made by relating respective peak areas to total ion chromatogram areas from the GC-MS [46].

\section{Ferric reducing antioxidant power (FRAP) assay}

The FRAP activity was determined by colorimetric method [47]. The reaction mixture containing $1 \mathrm{ml}$ of $0.05 \% \mathrm{O}$-Phenanthroline in methanol, $2 \mathrm{ml}$ ferric chloride $(200 \mu \mathrm{M})$ and $2 \mathrm{ml}$ of various concentrations (10 
a

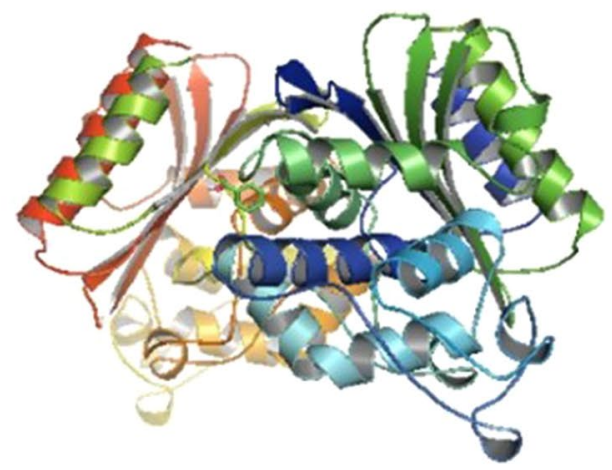

b
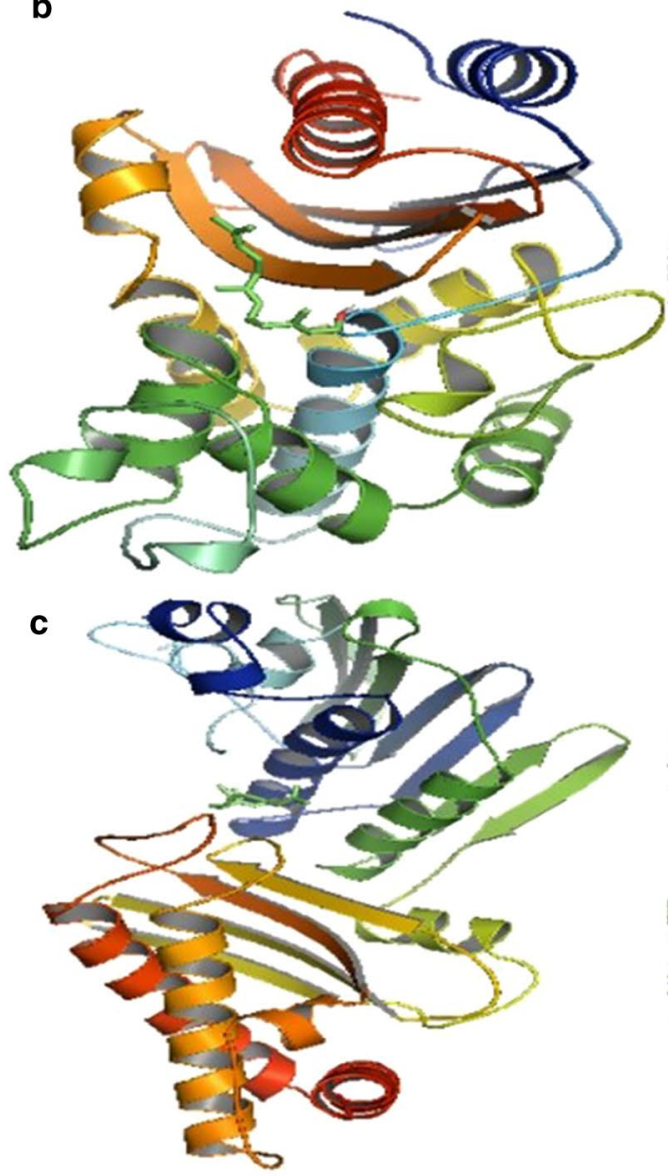
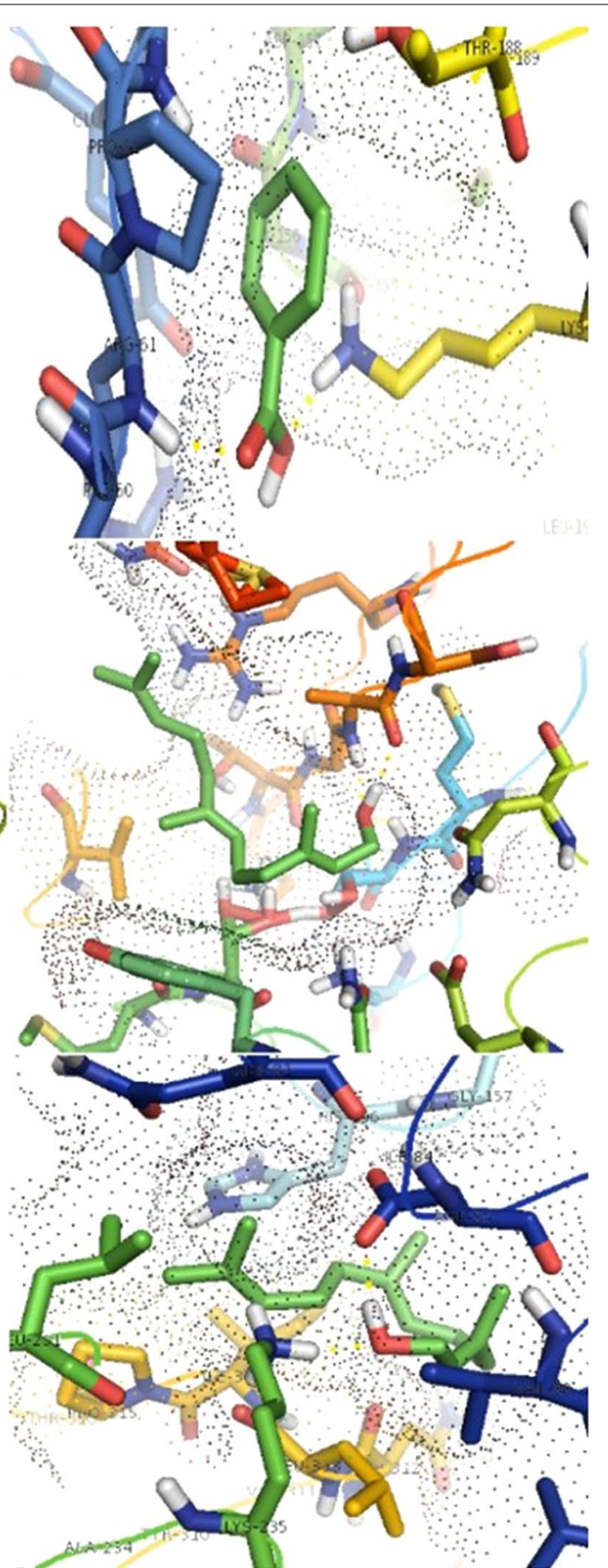

Fig. 4 Putative binding poses of ligands docked with TEM-72, SHV-2 and topoisomerase IV. The yellow dotted line indicates the H-bonding between the ligand and protein. a Molecular interaction of ligand benzoic acid-4-ethoxy-ethyl ester with TEM-72. b Molecular interaction of ligand farnesol acetate with SHV-2. c Molecular interaction of ligand farnesol acetate with Topoisomerase IV

to $50 \mu \mathrm{g}$ ) of $M$. minuta extracts, incubated at room temperature for $10 \mathrm{~min}$ and the absorbance of the sample was measured at $510 \mathrm{~nm}$. Moreover, the $\mathrm{IC}_{50}$ value was calculated. The experiments were performed in triplicate.

\section{DPPH free radical scavenging assay}

DPPH radical scavenging capacity and quenching ability of $M$. minuta leaf extract were estimated by following the methods reported by Zhang and Hamauzu [48]. Hexane: methanol extracts with different concentration 
$(10-50 \mu \mathrm{g} / \mathrm{ml})$ were mixed with DPPH solution $(0.15 \%)$ in methanol. Then it was incubated at dark for $10 \mathrm{~min}$ and the absorbance was read at $517 \mathrm{~nm}$. The antiradical activity was expressed as $\mathrm{IC}_{50}(\mu \mathrm{g} / \mathrm{ml})$, (the antiradical dose required to cause a $50 \%$ inhibition). Vitamin $\mathrm{C}$ was used as standard. The percentage inhibition was calculated using the following formula:

$$
\% \text { Scavenging }=\left[\left(\mathrm{A}_{\mathrm{o}}-\mathrm{A}_{\mathrm{s}}\right) / \mathrm{A}_{\mathrm{o}}\right] * 100
$$

where, $A_{o}$ is absorption of control, and $A_{s}$ is absorbance of sample and standards respectively. Moreover, the $\mathrm{IC}_{50}$ value was calculated [47]. The experiments were performed in triplicate. For both FRAP and DPPH assay, the reagent and buffer, free of the plant extract was used as control. All colorimetric assays were performed using ALERE microplate reader (Alere Medical Pvt Ltd, India, AM 2100).

\section{Superoxide dismutase (SOD) quantification}

SOD activity was done based on the reduction of superoxide-nitroblue tetrazolium complex according to a previously reported protocol [49]. The assay mixture contained $25 \mu \mathrm{l}$ cell supernatant (microbial cell) obtained by lysing the extract treated cells by Triton X-100, with $0.05 \mathrm{ml}$ of $\mathrm{L}$-methionine $(200 \mathrm{mM})$, and $0.05 \mathrm{ml}$ of nitro blue tetrazolium (1.5 mM NBT) solution. The enzyme activity was measured by measuring the reduction of NBT with xanthine oxidase as a hydrogen peroxide generating agent. The reaction mixture was illuminated for $30 \mathrm{~min}$ and the absorbance at $560 \mathrm{~nm}$ was measured against the control and test samples.

\section{Alkaline phosphatase (ALP) quantification}

Bacteria were cultured in MHB treated with $1 \mathrm{mg} / \mathrm{ml}$ of $M$. minuta leaf extract. After $14 \mathrm{~h}$ of incubation, cell free supernatants were collected for ALP assay. The assay was performed using ALP assay kit (Linear Chemicals, Montgat, Barcelona, Spain) by following the procedure as reported earlier [50]. To measure the ALP activity, extract treated samples were compared with control (cells without treatment) and the results were expressed in units/liter.

\section{Assessment of antibacterial activity}

The antibacterial activity of $M$. minuta leaves extract was performed by well diffusion method. Respective bacterial cultures were swabbed onto sterile petri plates containing Muller Hinton agar using sterile cotton swab. Then wells of $6 \mathrm{~mm}$ in diameter were made and $30 \mu \mathrm{l}(30 \mu \mathrm{g})$ of extracts and $30 \mu \mathrm{l}$ of streptomycin $(30 \mu \mathrm{g} / \mathrm{ml}$; used as positive control) were added to each well. Further, the plates were incubated at $37{ }^{\circ} \mathrm{C}$ for $14 \mathrm{~h}$. After incubation, the antibacterial activity was measured in terms of zone of inhibition $(\mathrm{mm})$. The experiments were performed in triplicate.

\section{Minimum inhibitory concentration (MIC)}

A twofold serial dilution of M. minuta extracts in Mueller-Hinton broth had been prepared in 96-well micro titre plate [51]. A standardized inoculum for each bacterial strain $\left(10^{6} \mathrm{CFU} / \mathrm{ml}\right)$ was prepared in each well. Streptomycin was used as a control. The plate was kept at $37{ }^{\circ} \mathrm{C}$ and incubated for $14 \mathrm{~h}$. MIC was calculated as the lowest concentration of the extracts inhibiting the visual growth of the test cultures on the agar plate.

\section{Lactate dehydrogenase (LDH) quantification}

The presence of the cytosolic enzyme (LDH) in the cell culture medium is the indicative of cell membrane damage. The LDH activity was determined by measuring the reduction of $\mathrm{NAD}^{+}$to $\mathrm{NADH}$ and $\mathrm{H}^{+}$during the oxidation of lactate to pyruvate. The activity was measured using LDH cytotoxicity assay kit (Linear chemicals, Spain), in accordance with manufacturer's instructions. The percent of LDH released from the cells was determined using the units/L of protein.

\section{Intracellular protein leakage}

The bacterial cultures were treated with $1 \mathrm{mg} / \mathrm{ml}$ of $M$. minuta leaf extract and incubated for $14 \mathrm{~h}$ at $37^{\circ} \mathrm{C}$. After incubation, the cells were centrifuged at $5000 \mathrm{rpm}$ for $10 \mathrm{~min}$ and the supernatants were collected. To determine the intracellular protein leakage, the supernatant was assayed according to the method of Bradford M.M [52].

\section{Scanning electron microscope observation (FE-SEM)}

The morphological changes of bacterial cells treated with M. minuta extracts, were observed under scanning electron microscope (VEGA3 TESCAN) and the procedures were performed according to Kockro et al. [53]. Bacterial cells $\left(10^{6} \mathrm{CFU} / \mathrm{ml}\right)$ were treated with $1000 \mu \mathrm{g} / \mathrm{ml}$ of extracts for $14 \mathrm{~h}$, centrifuged at $3000 \mathrm{~g}$ for $30 \mathrm{~min}$. The pellets were washed three times with phosphate buffered saline and pre-fixed with $10 \%$ formaldehyde for $30 \mathrm{~min}$. The pre-fixed cells were washed with $30,50,70,80,90$ and $100 \%$ of ethanol.

\section{In silico molecular docking studies}

The major constituents of $M$. minuta leaves extract (hexane: methanol) were subjected to molecular docking studies with three target proteins (TEM-72, PDB ID: 3P98; SHV-2, PDB ID: 1N9B; and Topoisomerase IV, PDB ID: 3LPS). Search of protein data bank confirmed presence of 3D structures of ESBL TEM-72 (at $2.10^{\circ} \mathrm{A}$ resolution), SHV-2 (at $0.90^{\circ} \mathrm{A}$ resolution) and Topoisomerase 
IV (at $0.98^{\circ} \mathrm{A}$ resolution) proteins. To analyze the nature of interactions with bioactive compounds, docking was carried out using AUTODOCK 4.0 and other docking procedures were followed as reported in our earlier work [50].All figures with structural representation were produced using PyMol [54].

\section{Statistical analysis}

The results obtained from cultured cells were analysed by Student's $t$ test. Statistical analysis were carried out using statistical package for the social sciences software (SPSS version 21; SPSS Inc., Chicago, USA) and $\mathrm{p}<0.05$ were considered as significant.

\section{Conclusion}

In the present study, the results indicated that $M$. minuta leaves extract showed antioxidant, antibacterial effect against food pathogens by disrupting their outer membrane and in silico docking analysis showed the major compound (benzoic acid-4-ethoxy-ethyl ester and farnesol acetate) exhibited good affinity towards of topoisomerase IV, SHV-2 and TEM-72. These results suggest that M. minuta may act as promising natural additives to prevent food spoilage bacteria. Moreover, the present study is a preliminary experiment to screen bioactive metabolite profile of $M$. minuta leaves and here we have used the GC/MS analysis as a tool to report the chemical constituents. Therefore, further studies are needed to validate the novel antibacterial bioactive molecules.

\section{Authors' contributions}

SA, RB designed and performed the research. RB did the sample collection. $\mathrm{PA}$ and $\mathrm{HS}$ analyzed the data and interpreted the results. SA and HS wrote the paper. All authors read and approved the final manuscript.

\section{Author details}

${ }^{1}$ Department of Food Science and Biotechnology, College of Life Science, Sejong University, Seoul 05006, Republic of Korea. ${ }^{2}$ Department of International Agricultural Technology, Graduate School of International Agricultural Technology, Seoul National University, Pyeongchang, Gangwon 25354, Republic of Korea. ${ }^{3}$ Institute of Green Bioscience and Technology, Seoul National University, Pyeongchang, Gangwon 25354, Republic of Korea. ${ }^{4}$ Department of Plant Biology and Biotechnology, Loyola College, Nungambakkam, Chennai 600034 , India.

\section{Acknowledgements}

The authors thank the Sejong University, Republic of Korea for their support and ANNA University, India for providing the SEM facility.

\section{Competing interests}

The authors declare that they have no competing interests.

\section{Availability of data and materials}

All data are fully available without restriction at the author's institutions.

Ethics approval and consent to participate Not applicable.

\section{Publisher's Note}

Springer Nature remains neutral with regard to jurisdictional claims in published maps and institutional affiliations.

Received: 14 July 2018 Accepted: 10 October 2018

Published online: 20 October 2018

\section{References}

1. Graybill JR (1988) Systemic fungal infections: diagnosis and treatment. I. Therapeutic agents. Infect Dis Clin N Am 2:805-825

2. Ng PC (1994) Systemic fungal infections in neonates. Archives of Disease in Childhood-Fetal and Neonatal Edition 71: F130-F135

3. Gonzalez CE, Venzon D, Lee S, Mueller BU, Pizzo PA, Walsh TJ (1996) Risk factors for fungemia in children infected with human immunodeficiency virus: a case-control study. Clin Inf Dis 23:515-521

4. Singh TK, Drake MA, Cadwallader KR (2003) Flavour of Cheddar cheese: a chemical and sensory perspective. Comp Rev Food Sci Food Saf 2:139-162

5. Lopez-Malo A, Maris Alzamora S, Palou E (2005) Aspergillus flavus growth in the presence of chemical preservatives and naturally occurring antimicrobial compounds. Int J Food Microbiol 99:119-128

6. Zengin G, Aktumsek A, Guler GO, Cakmak YS, Yildiztugay E (2011) Antioxidant properties of methanolic extract and fatty acid composition of Centaurea urvillei DC. subsp. hayekiana Wagenitz. Rec Nat Prod 5:123-132

7. Balasundram N, Sundram K, Samman (2006) Phenolic compounds in plants and agri-industrial by-products: antioxidant activity, occurrence, and potential uses. Food Chem 99:191-203

8. Salah N, Miller NJ, Paganga G, Tijburg L, Bolwell GP, Rice-Evans C (1995) Polyphenolic flavanols as scavengers of aqueous phase radicals and as chain-breaking antioxidants. Arch Biochem Biophys 322:339-346

9. Halliwell B, Gutteridge JMC (1981) Formation of a thiobarbituric-acidreactive substance from deoxyribose in the presence of iron salts: the role of superoxide and hydroxyl radicals. FEBS Lett 128:347-352

10. Cerruti PA, Trump BF (1991) Inflammation and oxidant stress in carcinogenesis. Cancer Cells 3:1-7

11. Gutiérrez RM, Mitchell S, Solis RV (2008) Psidium guajava: a review of its traditional uses, phytochemistry and pharmacology. J Ethnopharmacol $117: 1-27$

12. Hemalatha R, Nivetha P, Mohanapriya C, Sharmila G, Muthukumaran C, Gopinath M (2016) Phytochemical composition, GC-MS analysis, in vitro antioxidant and antibacterial potential of clove flower bud (Eugenia caryophyllus) methanolic extract. J Food Sci Technol 53:1189-1198

13. Rafiquzzaman SM, Ahmad MU, Lee JM, Kim EY, Kim YO, Kim DG, Kong IS (2016) Phytochemical composition and antioxidant activity of edible red alga Hypnea musciformis from Bangladesh. J of Food Pro Pres 40:1074-1083

14. Kitchen DB, Decornez H, Furr JR, Bajorath J (2004) Docking and scoring in virtual screening for drug discovery: methods and applications. Nat Rev Drug Discov 3:935-949

15. Bhardwaja TN, Garg A (1984) The antifertility effect of an Australian species of the aquatic fern Marsilea L. Indian Fern J 1:75-82

16. Bhattamisra SK, Khanna VK, Agrawal AK, Singh PN, Singh SK (2008) Antidepressant activity of standardized extract of Marsilea minuta Linn. J Ethno Pharmacol 117:51-57

17. Gupta RS, Kumar P, Sharma A, Bhardwaja TN, Dixit VP (2000) Hypocholesterolemic activity of Marsilea minuta in gerbils. Fitoter 71:113-117

18. Praneetha P, Swaroopa Rani V, Ravi Kumar B (2011) Hepatoprotective activity of methanolic extract of leaves of Marsilea minuta Linn against CCl4 induced hepatic damage in rats. Global J Pharmcol 5:164-171

19. Das Sukhen, Bala Niranjan, Kool Arpan, Thakur Pradip, Nandy Papiya, Basu Ruma (2015) Marsilea minuta plant extract mediated synthesis of gold nanoparticle for catalytic and antimicrobial applications. Int J Pharmacy 5:600-609

20. Gini TG, Jeya Jothi G (2015) In vitro screening of antibacterial and antifungal activity of Marsilea quadrifolia (Marsileaceae) Linn. extract. Am J Phytomed Clin Therap 3:313-329 
21. Inoue Y, Shiraishi A, Hada T, Hirose K, Hamashima H, Shimada J (2004) The antibacterial effects of terpene alcohols on Staphylococcus aureus and their mode of action. FEMS Microbiol Lett 237:325-331

22. Koo H, Rosalen PL, Cury JA, Park YK, Bowen WH (2002) Effects of compounds found in propolis on Streptococcus mutans growth and on glucosyltransferase activity. Antimicrob Agents Chemother 46:1302-1309

23. Lahimer MC, Ayed N, Horriche J, Belgaied S (2017) Characterization of plastic packaging additives: food contact, stability and toxicity. Arab J Chem 10:S1938-S1954

24. Kumar S, Pandey AK (2013) Chemistry and biological activities of flavonoids: an overview. Sci World J 29:1-16

25. Sulaiman S, Ibrahim D, Kassim J, Sheh-Hong L (2011) Antimicrobial and antioxidant activities of condensed tannin from Rhizophora apiculata barks. J Chem Pharm Res 3:436-444

26. Pereira DM, Valentão P, Pereira JA, Andrade PB (2009) Phenolics: from chemistry to biology. Molecules 14:2202-2211

27. Kumaran A, Karunakaran JR (2007) In-vitro antioxidant activities of methanol extracts of five Phyllanthus species from India. LWT Food Sci Techol 40:344-352

28. Zahan R, Ripa FA, Alam MB, Haque MA, Mosaddik MA, Nahar L (2011) Hypoglycemic and in vitro antioxidant effects of methanolic extract of Marsilea quadrifolia Plant. Pharmacogn J 3:86-92

29. Miladi H, Zmantar T, Chaabouni Y, Fedhila K, Bakhrouf A, Mahdouani K, Chaieb K (2016) Antibacterial and efflux pump inhibitors of thymol and carvacrol against food-borne pathogens. Microb Path 99:95-100

30. Gupta RN, Kartik V, Manoj P, Singh PS, Alka G (2010) Antibacterial activities of ethanolic extracts of plants used in flok medicine. Int J Res Ayurveda Pharm 1:529-535

31. Ríos JL, Recio MC (2005) Medicinal plants and antimicrobial activity. J Ethnopharmacol 100:80-84

32. Tran HBQ McRae JM, Lynch F, Palombo EA (2010) Identification and bioactive properties of endophytic fungi isolated from phyllodes of Acacia species. Curr Res Tech Edu Top Appl Microb Biotechol. 17:377-382

33. Prakash A, Suneetha V (2014) Punica granatum (Pomegranate) Rind extract as a potent substitute for $L$ ascorbic acid with respect to the antioxidant activity. Res J Pharm Biol Chem Sci 5:597-603

34. Burt S (2004) Essential oils: their antibacterial properties and potential applications in foods - a review. Int J Food Microbiol 94:223-253

35. Shirwaikar A, Punitha ISR (2007) Antioxidant studies on the methanol stem extract of Coscinium fenestratum. Nat Prod Sci 13:40-45

36. Dwyer DJ, Kohanski MA, Hayete B, Collins JJ (2007) Gyrase inhibitors induce an oxidative damage cellular death pathway in Escherichia coli. Mol Syst Biol 3:91. https://doi.org/10.1038/msb4100135

37. Xu F, Cheng G, Hao H, Wang Y, Wang X, Chen D, Peng D, Liu Z, Yuan Z, Dai M (2016) Mechanisms of antibacterial action of Quinoxaline 1,4-di-N-oxides against Clostridium perfringens and Brachyspira hyodysenteriae. Front Microbiol 7:1948. https://doi.org/10.3389/fmicb.2016.01948.eCollection

38. Tsai GJ, Su WH (1999) Antibacterial activity of shrimp chitosan against Escherichia coli. J Food Prot 62:239-243
39. Henie EFP, Zaiton H, Suhaila M (2009) Bacterial membrane disruption in food pathogens by Psidium guajava leaf extracts. Int Food Res J 16:297-311

40. Burt SA, Reinders RD (2003) Antibacterial activity of selected plant essential oils against Escherichia coli O157:H7. Lett Appl Microbiol 36:162-167

41. Livermore DM (1995) Beta-lactamases in laboratory and clinical resistance. Clin Microbiol Rev 8:557-584

42. Knox JR (1995) Extended-spectrum and inhibitor-resistant TEM-type beta-lactamases: mutations, specificity, and three-dimensional structure. Antimicrob Agents Chemother 39:2593-2601

43. Zechiedrich EL, Cozzarelli NR (1995) Roles of topoisomerase IV and DNA gyrase in DNA unlinking during replication in Escherichia coli. Genes Dev 9:2859-2869

44. Randhawa V, Jamwal R (2011) Molecular modeling and virtual screening studies of NDM-1 beta lactamase for identification of a series of potent inhibitors. Int Res J Biochem Bioinform 1:95-102

45. Somersalo S, Karunen P, Aro EM (1986) The acyl lipid composition of wheat leaves and moss protonemata using a new, non-carcinogenic extraction solvent system. Physiol Plant 68:467-470

46. Jadhav V, Kalase V, Patil P (2014) GC-MS analysis of bioactive compounds in methanolic extract of Holigarna grahamii (wight). Kurz. 2:35-39

47. Benzie IF, Szeto YT (1999) Total antioxidant capacity of teas by the ferric reducing/antioxidant power assay. J Agric Food Chem 47:633-636

48. Zhang D, Hamauzu Y (2004) Phenolics, ascorbic acid, carotenoids and antioxidant activity of broccoli and their changes during conventional and microwave cooking. Food Chem 88:503-509

49. Gupta AS, Webb RP, Holaday AS, Allen RD (1993) Overexpression of superoxide dismutase protects plants from oxidative stress (induction of ascorbate peroxidase in superoxide dismutase-overexpressing plants). Plant Physiol 103:1067-1073

50. Arokiyaraj S, Choi SH, Lee Y, Bharanidharan R, Hairul-Islam VI, Vijayakumar B, Oh YK, Dinesh-Kumar V, Vincent S, Kim KH (2015) Characterization of Ambrette seed oil and its mode of action in bacteria. Molecules 20:384-395

51. NCCLS (National Committee for Clinical Laboratory Standards) Approved Standard M100-S12. Wayne. PA, NCCLS (2002). Methods for dilution antimicrobial susceptibility tests of bacteria that grow aerobically

52. Bradford MM (1976) A rapid and sensitive method for the quantitation of microgram quantities of protein utilizing the principle of protein-dye binding. Anal Biochem 72:248-254

53. Kockro RA, Hampl JA, Jansen B, Peters G, Scheihing M, Giacomelli R (2000) Use of scanning electron microscopy to investigate the prophylactic efficacy of rifampin-impregnated CSF shunt catheters. J Med Microbiol 49:441-450

54. Morris GM, Goodsell DS, Halliday RS, Huey R, Hart WE, Belew RK, Olson AJ (1998) Automated docking using a Lamarckian genetic algorithm and an empirical binding free energy function. J Comp Chem. 19:1639-1662
Ready to submit your research? Choose BMC and benefit from:

- fast, convenient online submission

- thorough peer review by experienced researchers in your field

- rapid publication on acceptance

- support for research data, including large and complex data types

- gold Open Access which fosters wider collaboration and increased citations

- maximum visibility for your research: over $100 \mathrm{M}$ website views per year

At BMC, research is always in progress.

Learn more biomedcentral.com/submissions 